Ann. Biol. anim. Bioch. Biophys., I975, 15 (2), I9I-204.

\title{
FOLLICULAR GROWTH DURING THE NORMAL CYCLE AND AFTER TREATMENT WITH PROGESTAGENS IN THE EWE
}

\author{
Th. A. M. KRUIP and A. BRAND \\ Clinic for Veterinary Obstetrics, Gynecology and A. I., \\ State University, Utrecht. (Netherlands)
}

\begin{abstract}
SUMMARY
Tertiary follicles in the ovaries of Texel sheep are examined micromorphologically and cytochemically during an oestrous cycle, and during and after a I 3 -days treatment with $6 x$-methylI $7 \alpha$-acetoxy-progesterone (MAP). At the same time, we investigated oestradiol-I $7 \beta$ concentration in the liquor folliculi during the oestrous cycle and MAP treatment. Two follicular growth waves are observed during an oestrous cycle. The first growth wave is observed from days I to Io, and the second wave from days 6 to 17 (day o). Only small amounts of oestradiol- $17 \beta$ are found in the follicles of the first growth wave and follicles of the second growth wave up to and including day I4. Maximum concentration occurs on day 16 , with a mean value of $8.7 \mu \mathrm{g}$ per Ioo $\mathrm{g}$ liquor; only $3.8 \mu \mathrm{g} / \mathrm{loo} \mathrm{g}$ of liquor is found during oestrus. Cytochemical study offers an explanation for these differences in oestrogen synthesis on the various days of the cycle. From days I to 16 , the follicles show $3 \beta$-hydroxysteroid dehydrogenase $(3 \beta$-HSD), as well as $17 \beta$-hydroxysteroid dehydrogenase ( 7 - $\beta$-HSD) activity, in the theca interna. This activity increases with the size of the follicles. No $17 \beta$-HSD activity is detected in the preovulatory follicles during oestrus : absolutely no steroid dehydrogenase activity is found in the membrana granulosa. Treatment with MAP leads to a prolongation of follicular life-span. A change in the follicles is observed, i.e. $3 \beta$-HSD activity, is detected in the membrana granulosa of follicles, which lasted at least 6 days. Furthermore, observations indicate that MAP treatment does not prevent the development of new follicular growth, and inhibits only slightly follicular steroid synthesis. The termination of MAP treatment is followed by a rapid growth of new follicles. Some of these fast-growing follicles also show $3 \beta$-HSD activity in the membrana granulosa, and are found in animals in oestrus. Besides $3 \beta-H S D$ activity in the membrana granulosa, the follicles also show I $_{7} \beta-\mathrm{HSD}$ activity in the theca interna. This means that the ovaries are able to produce oestrogens during the first oestrus following treatment with progestagens. The follicles that persist during treatment may also remain for some time after termination of the treatment, which is followed by atresia or ovulation. The interval between the onset of oestrus and ovulation is normal. Oocytes released during or shortly after oestrus can originate from normal follicles, fast-growing follicles and persisting follicles. In the discussion of the results of this investigation, reference is made to the generally accepted subfertility in first oestrus after treatment with progestagens.
\end{abstract}




\section{INTRODUCTION}

During the last few years progestagens have been used on a large scale in farm animals for induction of synchronized oestrus. In these experiments attention has been paid to the rate of synchronization and fertility. In I968, Robinsos already stated that a much clearer general picture of the reproductive physiology of farm animals was needed to improve artificial oestrus control.

It is important to know what happens to the follicle population during the normal oestrous cycle and after progestagen treatment. Therefore, we made an extensive study of sheep, examining some of the micromorphological, cytochemical and biochemical aspects of follicles during the normal cycle and after MAP treatment, and paying special attention to the day of the cycle on which MAP treatment was started.

\section{MATERIALS AND METHODS}

\section{Cyclic animals}

A group of 39 maiden ewes aged I $1 / 2$ years with a normal oestrous cycle was used for micromorphological study. The ovaries were fixed in Bouin on various days of the oestrous cycle, embedded in paraplast and sectioned serially at $10 \mu$. Day o was the day on which the ewes showed standing heat. All tertiary follicles were counted and subdivided into normal and atretic follicles (Brand and De JoNG, I973).

A group of Ioo ewes was utilized for a biochemical analysis of the ovaries to detect oestrogens and progestagens. This analysis was performed by gas chromatography (BRAND and VAX DER Horst, I972).

A group of 54 maiden ewes ages I I/ 2 years was used for a cytochemical study. Three animals were killed on each day of the cycle. The ovaries were deepfrozen in cooled isopentane. Sections of $10 \mu$ were cut in a cryostat at- $20^{\circ} \mathrm{C}$. The sections were collected as near as possible to the largest diameter of the follicle. The diameter was measured by projection of the cytochemical picture on a table. The unfixed slices were incubated in different media (KRUIF, 1973) in order to determine, among other enzymes:

r. $3 \beta$-hydroxysteroid clehydrogenase (3 $\beta$-HSD) using the method of DeANE et al. (1966). This enzyme is essential in steroid synthesis and gives information about the conversion of biological inactive $\Delta_{5} 3 \beta$-hydroxysteroids into biological active $\Delta_{4}$ 3-ketosteroids.

2. I $7 \beta$-hydroxysteroid dehydrogenase ( $\mathrm{I} 7 \beta$-HSD) using the method of KeLLoG and (iLENNER (1960). This enzyme provides information on the reversible conversion of oestradiol-I $7 \beta$ to oestron, thus indicating oestrogen metabolism.

3. alkaline phosphatase (AP) using the method of Gomori (1939). This enzyme can be demonstrated in all steroid-producing cells (DEANE, I952), and may play a role in hydrolysis of steroid phosphates (Arvy, 1960).

Enzyme activity was evaluated according to the anount of colored precipitation obtained using a subjective scale varying from $\mathbf{x}+$ to $+t$.

\section{MAP-treated animals}

A group of 15 maiden ewes aged I I/2 years was utilized for micromorphological study. Sponges impregnated with $60 \mathrm{mg} 6 \alpha$-methyl-1 $7 \alpha$-acetoxy-progesterone (MAP) were inserted into the vaginas of the ewes. The animals were treated in groups of 3 each on days 2,5, 8, I 2 and I 5 , respectively, of the oestrous cycle. The animals were slaughtered after $\mathrm{I}_{3}$ days ( $\left.\mathrm{T} \mathrm{I}_{3}\right)(\mathrm{T}=$ treatment). The ovaries were collected, treated and examined as described above. 
lorty-eight maiden ewes aged I I/2 years were used for cytochemical analysis. The same sponges were inserted into the vaginas of ewes divided into groups of $I_{5}$ each on days 4,10 and $I_{5}$, respectively. The sponges were removed after 13 days. Three or 4 animals from each group (day + group, day Io group and day I 5 group) were killed at o hour ( $\left.\mathrm{T}_{13}\right), 24$ hours ( $\left.\mathrm{T}_{1} 3+\mathrm{I}_{1}\right), 4^{8}$ hours $\left(\mathrm{T}_{1} 3+2\right)$ and 72 hours $\left(\mathrm{T}_{13}+3\right)$, respectively, after sponge withdrawal. In order to establish the onset of oestrus after sponge withdrawal, ewes were run with vasectomized rams and continually observerl. The ovaries were deep-frozen, treated and examined as described above.

\section{RESULTS}

\section{Cyclic animals}

Micromorphological findings.

During the normal oestrous cycle there is no significant variation in the absolute or relative number of normal and atretic tertiary follicles. The normal follicles $\geqslant 2 \mathrm{~mm}$ in diameter ( $\geqslant I \mathrm{~mm}^{3}$ ) have two growth waves (fig. I). The first growth wave was

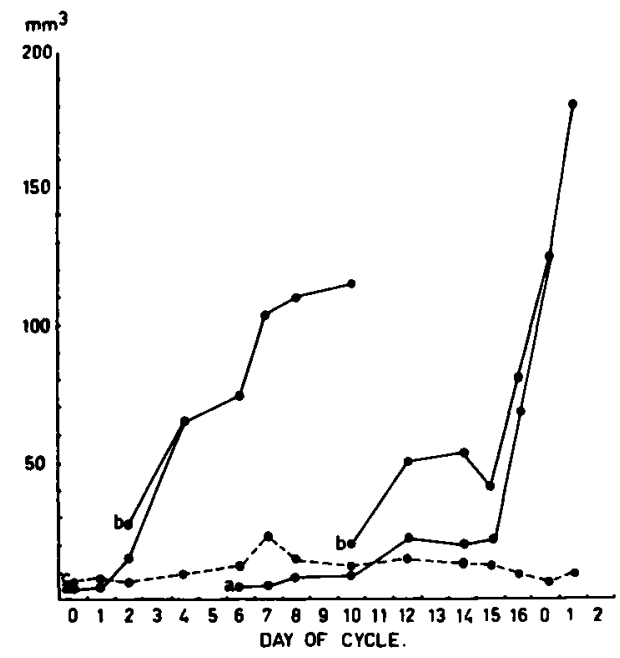

Jiti. I. -.. Mean volume of normal (o-

$(\geqslant 2$ mm in diameter) during the oestrous cycle

observed from day I to day Io, and the second from day 6 to day I7 (day o). There were more normal follicles present during the start of the first growth wave than at the end (day Io), when only one normal follicle was found. The number of normal follicles $\geqslant 2 \mathrm{~mm}$ in diameter between days 6 and $\mathrm{r}_{5}$ ranged from one to twelve. On days 16 and 0,6 ewes showed a total of eleven normal follicles belonging to the second growth wave. A reduction in the number of normal follicles $\geqslant 2 \mathrm{~mm}$ in diameter, however, occurred at the latest stages of both growth waves. Follicles of the second growth wave showed a tremendous increase in size on days 16 and 0 . The first and second growth waves were different in some respects. Follicles of the first growth wave increased more gradually in size than those of the second. On an average, there were more normal follicles present at the end of the second growth wave (two) than at the 
end of the first (one). Normal follicles of the first growth wave disappeared by atresia, and the last ones of the second wave by ovulation. A preovulatory growth spurt was only observed at the end of the second growth wave, and the follicular wall of the normal follicles at the end of the first growth wave appeared to be thinner than at the end of the second wave.

\section{Biochemical findings.}

Oestradiol-I $7 \beta$ concentration in the liquor folliculi during the oestrous cycle is given in figure 2. Oestradiol- $I 7 \beta$ could not be detected in thirteen small follicles ( $<30 \mathrm{mg}$ liquor folliculi). It was found in seven out of nineteen medium-sized follicles (30-75 $\mathrm{mg}$ liquor folliculi) and in forty-six out of seventy-nine large follicles $(>75 \mathrm{mg}$ liquor folliculi). With the exception of a few follicles in which high concentrations of oestradiol were found about days 4 and 8 , low levels were present from days I to I4. There was a rapid increase from day $\mathrm{I} 4$ onward, and a maximum of $8.7 \mu \mathrm{g} / \mathrm{I} 00 \mathrm{~g}$ liquor was observed on day 16 . On day o, the level had decreased by 56 percent, and on day $I$ it was equal to the average level of the dioestrous period. The percentage of medium and large-sized follicles with oestradiol-I $7 \beta$ was highest on days $I_{5}$ and I6 (95 percent). On day 0 , only 35 percent of the follicles were positive, and from days I to $\mathrm{I} 3$ oestradiol-I $7 \beta$ was only detected in 23 percent of the medium and large-sized follicles examined.

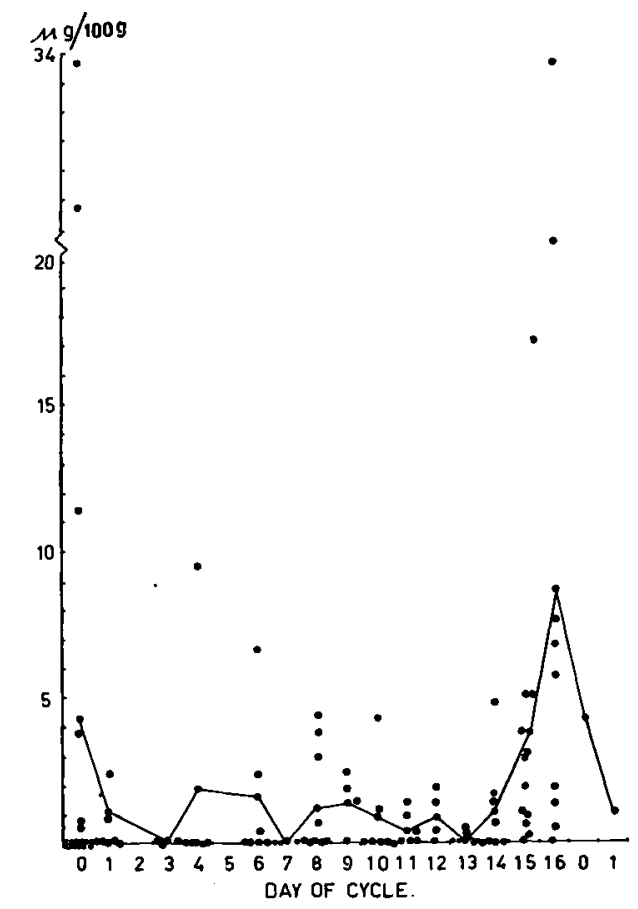

lig. 2. - Concentration of oestradiol in tertiary follicles and course of mean concentration during the oestrous cycle 


\section{Cytochemical findings.}

Three types of follicles were distinguished according to size and cytochemical character (table $I$ ) within the group of tertiary follicles $\geqslant 3 \mathrm{~mm}$ in diameter.

Type $\mathrm{I}, \leqslant 6.5 \mathrm{~mm}$ with $3 \beta-H S D, I_{7} \beta$-HSD and AP activities in the theca interna, Type $2, \geqslant 6.5 \mathrm{~mm}$ with $3 \beta$-HSD and AP activities in the theca interna, Type 3, 3-7 $\mathrm{mm}$ with only AP activity in the theca interna.

TABI,E I

Cytochemical appearance of tertiary follicles in the ovary of the Texel sheep during the oestrous cycle (type I, 2 and 3 ) and after MAP-treatment (type 4 and 5)

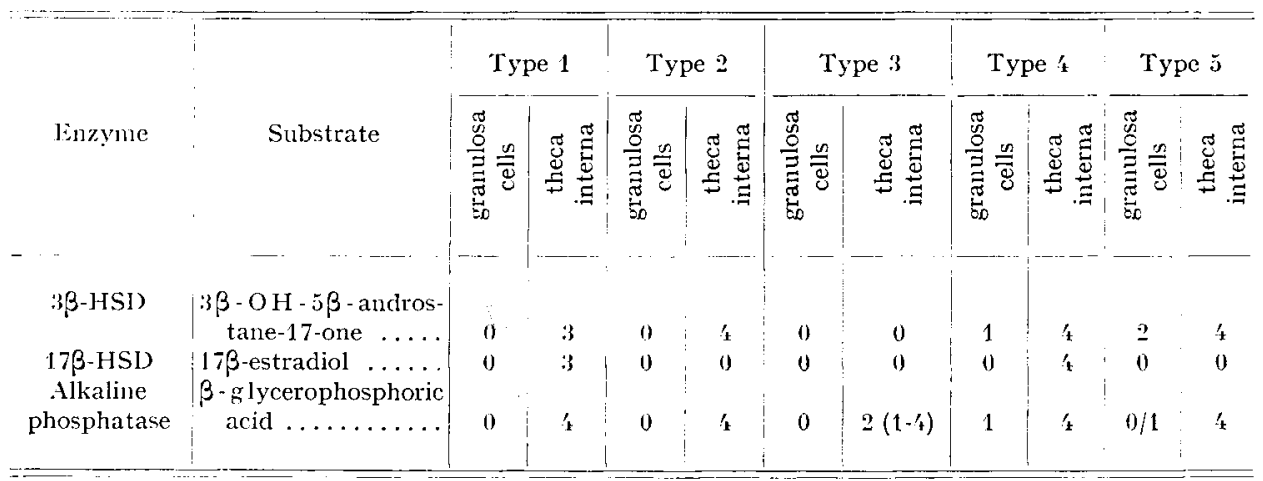

The three enzymes above could not be detected in the granulosa cells. Follicles of type I were observed from days I to 16 , included. $3 \beta-\mathrm{HSD}$ and $17 \beta-\mathrm{HSD}$ activities increased with the size of the follicle and were estimated at $3+$ in follicles of 3 to $6 \mathrm{~mm}$ in diameter which were present from days I to I6. In most cases, the activity was $4+$ on day I6. AP activity was always maximal in this type of follicle. Follicles of type 2 , in which no I $7 \beta$-HSD activity could be detected, were observed around day 7 and during oestrus. $3 \beta$-HSD activity was maximal only in preovulatory follicles; it was submaximal to weak in large follicles around day 7 . AP activity in these follicles was always maximal on day o and often around day 7 . Deep-frozen slices are not so suitable for a morphological description. Nevertheless, it was possible to conclude that follicles on day o were characterized by a round shape, compact membrana granulosa and a well-developed theca interna. On the other hand, some follicles around day 7 were oval and pear-shaped with a thin membrana granulosa and loosening granulosa cells.

Follicles of type 3 could be observed on every day of the cycle. They were characterized by a deviated shape, a thin and often chaotically organized membrana granulosa and a thin theca interna.

\section{MAP-treated animals}

\section{Micromorphological findings.}

When $60 \mathrm{mg}$ of MAP were administered intravaginally for $\mathrm{I}_{3}$ days (TI3) on day $2,5,8, \mathrm{I} 2$ or $\mathrm{I}_{5}$, normal follicles of increasing volume (fig. 3) were present at the 
end of the treatment in the period from days $2 \operatorname{Tr} 3$ to $\operatorname{I}_{2} \mathrm{~T} \mathrm{~T}_{3}$. The average follicular volume on day ${ }_{2} \mathrm{~T} 3$ was more than twice that of the largest preovulatory follicles in untreated cwes. Besides these large follicles, a total of two small ( $\geqslant 2 \mathrm{~mm}$ ) normal follicles were present on day I2'Tr $_{3}$. The large follicles on day I2'TI3 showed a thin membrana granulosa (4 cell layers) and a thin theca interna. On day ${ }_{5} \mathrm{Tr}_{3}$, some large atretic follicles and nine (in 3 ewes) small normal follicles could be observed.

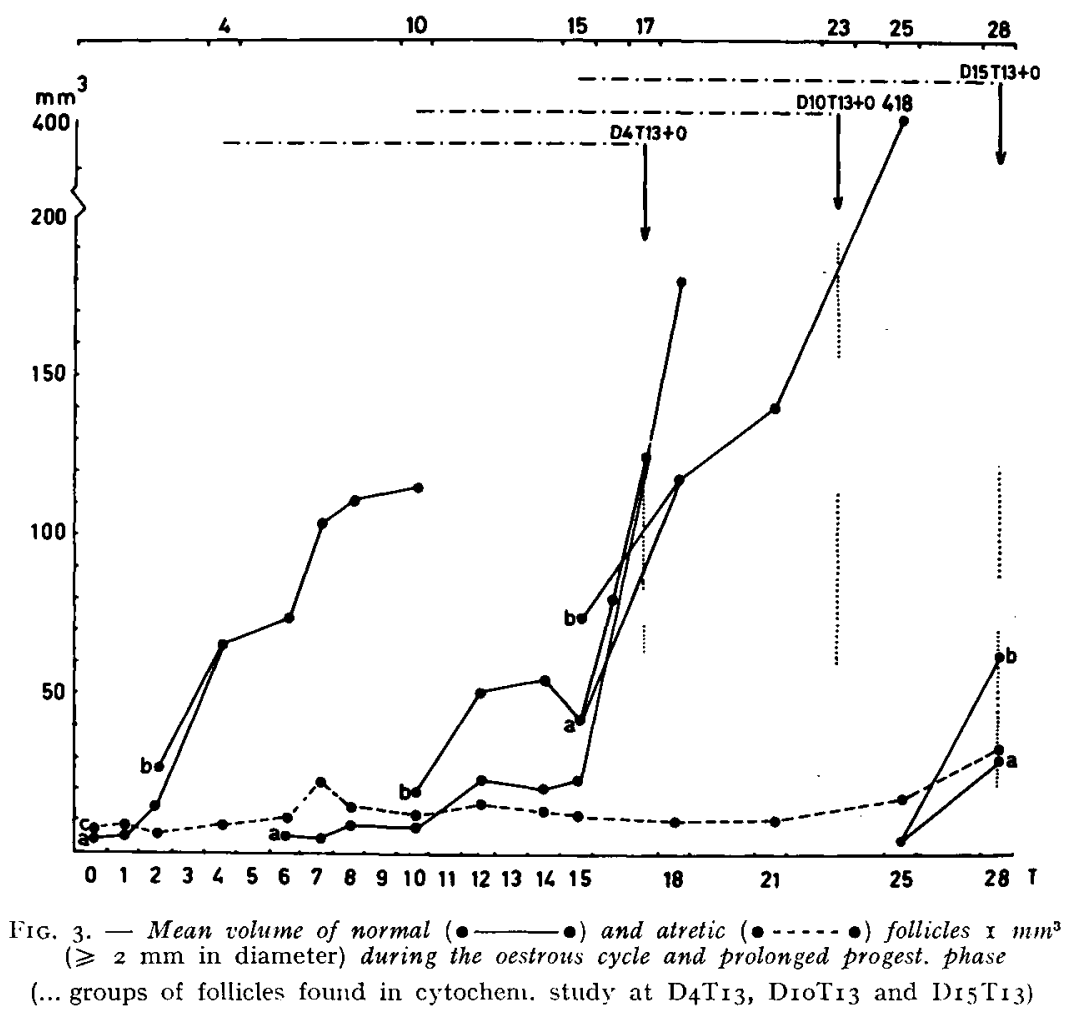

\section{Cytochemical findings.}

Besides the already-mentioned follicles of types I, 2 and 3 (table I), follicles with $3 \beta-H S D$ activity in the granulosa cells were also observed after MAP treatment. In this group, follicles with (type 4) and without (type 5) I7 $\beta$-HSD activity could be distinguished in the theca interna. AP activity was always present in the membrana granulosa of type 4 follicles and only rarely in type 5 follicles. The distribution of the various types of follicles in the three groups was not the same (table 2). The distribution and average size of the various types of follicles are given in table 2 . It appears that follicles of type 4 are only present in the day 4 group and in animals in oestrus. Type 5 follicles were seen only once in the day 4 group, twice in the day I 5 group, and very often in day ro group. These follicles were observed at day IoTr 3 , as well as during oestrus in the day ro group, and were characterized by their size (often > $7 \mathrm{~mm}$ in diameter). The average size of type 4 follicles was $5.2 \mathrm{~mm}$ (range $4.0-7.0$ ) and that of type 5 follicles $6.2 \mathrm{~mm}$ (range 3.2-8.8) (table 2 ). Recently ovulated follicles 
with $I_{7} \beta$-HSD activity in the theca lutein cells were observed in all three groups. Follicles of types I and 2 were present in all groups on TI3. In the day 4 group there were more follicles of type 2 than of type I on TI3. In both other groups type I was most common on TI3. A comparison of the size of type $\mathrm{I}$ follicles on day roTI3 and day ${ }_{5} \mathrm{Ti}_{3}$ indicates that the former have a larger mean size than the latter (table $2, *$ and $* *)$.

TABLE 2

Distribution of the distinguished types of tertiary follicles in three different main-groups and twelve sub-groups of MAP-treated animals

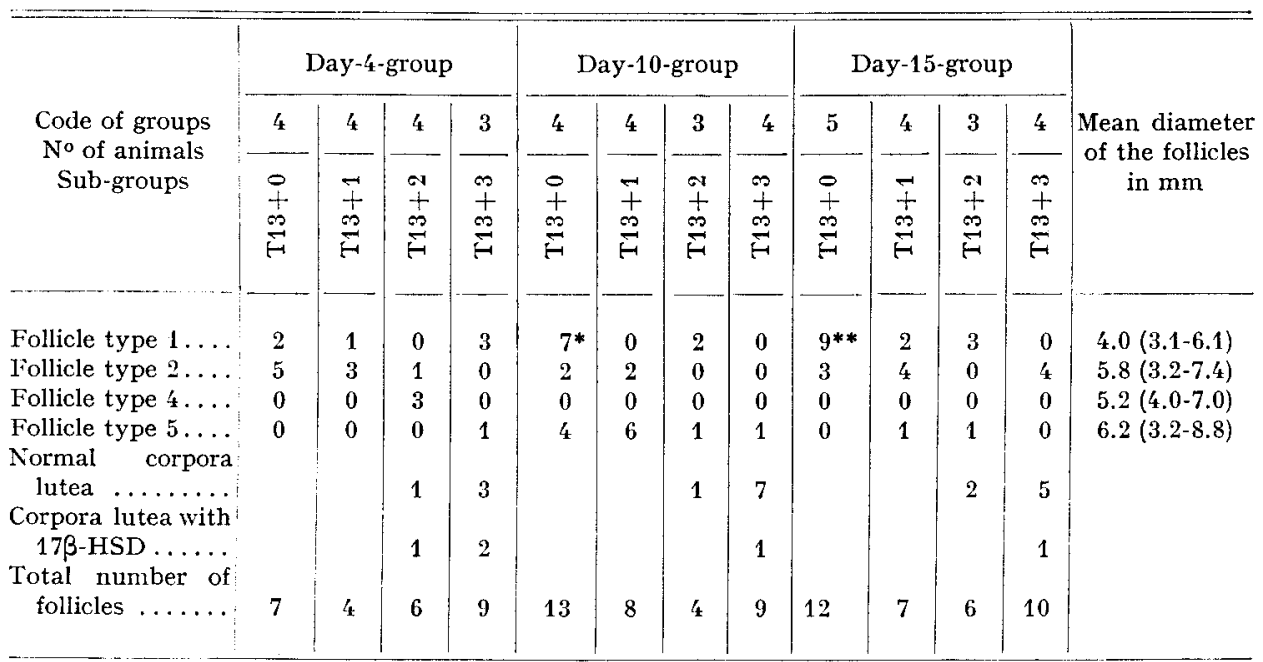

$\mathrm{T} 13=13$ days MAP-treatment

$\mathrm{T} 13+0:$ at the end of treatment

$\mathrm{T} 13+1: 24$ hours after end of treatment.

* variation in size : $3.1-6.0 \mathrm{~mm}$ in diameter.

** variation in size $: 3.8-4.8 \mathrm{~mm}$ in diameter.

\section{Oestrus and ovulation.}

The average time between sponge removal and onset of oestrus for the three groups was $27 \mathrm{I} / 2$ hours (day 4 group), $26 \mathrm{I} / 2$ hours (day Io group) and $34 \mathrm{I} / 2$ hours (day I $_{5}$ group), respectively. No ovulation occurred before 24 hours after the onset of heat. All the animals slaughtered 27 hours after the onset of oestrus or later had ovulated.

\section{DISCUSSION AND CONCLUSIONS}

Micromorphological and cytochemical findings show two growth waves of normal tertiary follicles $\geqslant 2 \mathrm{~mm}$ in diameter during the oestrous cycle. The difference in the length of the first growth wave (from days I to Io in the micromorpho- 
logical study and from days $I$ to 7 in the cytochemical findings) can be explained by the use of different criteria for the functional state of the tertiary follicle.

$3 \beta-\mathrm{HSD}$ and $\mathbf{r} 7 \beta-\mathrm{HSD}$ activities in the theca interna cells of follicles from day I up to and including day 16 suggest that these cells are involved in the synthesis of oestradiol-I $7 \beta$ which is released in the follicular fluid and ovarian venous blood. Oestradiol-I $7 \beta$ synthesis could be predicted to be weak or low from days $I$ to $I 6$, or maximal on day 16 and nihil on day 0 , by knowing the differences in $3 \beta-H S D$ activity and whether or not $17 \beta$-HSD was present. Although small increased levels of oestradiol-I $7 \beta$ were seen around day 4 and day 8 , it can be concluded that this prediction corresponds to the oestradiol-I $7 \beta$ concentration found in the follicular fluid (fig. 2) and in the ovarian venous blood (MoOre et al., I969; SCARAMuzzI et al., I970 ; Cox et al., I97 I ; BJERSING et al., I972). This agreement indicates a close relation between morphology and function. Oestrogens found in the follicular fluid on day o must, therefore, be synthesized on day 16 or earlier. The inability of preovulatory follicles to synthesize oestradiol-I7 $\beta$ may be caused by preovulatory $\mathrm{L}_{\mathrm{H}}$ surge (Moor, r974). The lack of $I 7 \beta-H S D$ activity in follicles $\geqslant 6.5 \mathrm{~mm}$ around day 7 may be a first sign of atresia of follicles at the end of the first growth wave. Since small tertiary follicles show $3 \beta-\mathrm{HSD}$ as well as $\mathrm{I}^{\beta} \beta-\mathrm{HSD}$ activity, and large follicles $\geqslant 6.5 \mathrm{~mm}$ only $3 \beta$-HSD activity, it is concluded that the former follicles (type $\mathrm{I}$ ) are younger than the larger ones (type 2). Follicles without steroid dehydrogenase activity are always considered as atretic.

In MAP-treated animals, the large normal follicles which were seen at the end of the treatment from day $2 \mathrm{~T}_{3} 3$ to day I2TI 3 must represent a continuation of the second growth wave of normal follicles $\geqslant 2 \mathrm{~mm}$ in diameter. The phenomenon of the thin membrana granulosa (4 cell layers) and the thin theca interna has already been noticed at the end of the first growth wave of the normal oestrous cycle. On day ${ }_{5} \mathrm{Tr} 3$ there were no longer any normal follicles of this prolonged growth wave, but only atretic ones were present. This means that, based on micromorphological critera during the MAP treatment, normal follicles of the prolonged growth wave became atretic prior to day ${ }_{5} \mathrm{~T}_{13}$. The fact that on $\mathrm{T}_{13} 3$ of the day $\mathrm{I}_{2}$ group a total of two small normal follicles ( $\geqslant 2 \mathrm{~mm}$ in diameter) were found in 3 ewes, whereas on TI3 of the day I5 group there were nine, suggests that a new growth wave developed already before day 2 'TI3.

Findings in the cytochemical study of the day $4 \operatorname{Tr} 3$ and day $I_{5} \operatorname{Tr} 3$ groups are in agreement with the micromorphological study. Besides large follicles (type 5) on day IoTr3, many small follicles (type I) could be observed which we could not detect in the micromorphological study on day $8 \mathrm{~T}$ I3. Considering the cytochemical criteria, this means that a new follicle growth wave had already started earlier than mentioned above, i.e. before day Io'Tı 3 . A comparison of the size of type I follicles on day Io' $I_{3}$ and day $\Upsilon_{5} \mathrm{TI}_{3}$ (table $2,{ }^{*}$ and ${ }^{* *}$ ) suggests that the groups of follicles belong to different generations. This would imply that during MAP treatment different new growth waves can start. However, since the different results of both studies are based on small groups of animals, they can be explained by the use of different criteria as mentioned above. Further detailed studies on more animals have to be done. Another question is whether, under these circumstances, treatment influences steroid synthesis in the ovary. This will be discussed later.

At the end of MAP treatment in the day ro group and also during the period 
after sponge removal in the other groups, some large follicles showed $3 \beta$-HSD activity in the granulosa cells. This phenomenon could not be detected during the normal oestrous cycle in sheep (KRUIP, I972 ; MOOR et al., I97 I). It is usually found in preovulatory follicles of rat (PRAHBU and WEISz, I970), cow (LOBEL and LEVY, I968), horse (KRUIP, unpublished) and pig (BJERSING, I967). The appearance of $3 \beta$-HSD activity in preovulatory follicles can be interpreted as a sign of luteinization which, according to BJERSING, is accompanied by increasing progesterone synthesis. In our opinion, the presence of $3 \beta$-HSD in granulosa cells of type 4 and type 5 follicles must, therefore, be a sign of luteinization.

Type 4 follicles with $I_{7} \beta$-HSD in the theca interna were observed for the first time 30 hours after sponge withdrawal and in animals in heat. Seventeen- $\beta-H S D$ activity was also observed in recently ovulated follicles, which indicates that these corpora lutea originate from type 4 follicles. This means that type 4 follicles are very fast-growing functional follicles, occurring independently of the day on which MAP treatment was started. The presence of type 4 follicles during oestrus after MAP treatment suggestsoestrogen synthesis which was not seen on day o of the normal oestrous cycle. This is in agreement with findings indicating that maximal concentration of oestradiol-I $7 \beta$ after MAP treatment occurs during oestrus (VAN DER HORST and BRAND, I97I), and not on the day before oestrus as during the normal cycle. Type 5 follicles were the large follicles at the end of MAP treatment started around day Io. As already stated, these follicles must represent the persisting follicles of the second growth wave which was also observed by DzIuk et al. (I964). This implies that during the prolongation of the second growth wave, the large follicles which were type 2 became type 5 . Since these were the only large follicles present in the ovaries of animals in heat, it is supposed that they are functional and able to ovulate, as already suggested by ZimbELMAN and SMiTh (I966) in cattle.

The phenomenon of luteinization can be explained as a result of :

I) a form of atresia, as found by Guthrie et al. (r970) in cattle. However, we are of the opinion that type 4 ans 5 follicles are functional.

2) disturbance of the relation between the oocyte and the granulosa cells. In persisting follicles the oocytes are aging, which leads to luteinization of granulosa cells (Prahbu and Weisz, I970; Salisbury and HART, I970). These explanations refer only to type 5 follicles.

3) a rapid follicular growth which disturbs the normal process of development of tertiary follicle to preovulatory follicle, as described by Moon et al. (I97I). This applies only to type 4 follicles.

4) an alteration in the interval between the onset of oestrus and maximal $\mathrm{LH}$ release, which normally occurs during oestrus. However, after progestagen treatment, it takes place prior to the onset of oestrus (Cumming et al., I973). This may be the reason for early luteinization in type 4 and 5 follicles. In our material, we found a normal interval between onset of oestrus and ovulation, which is difficult to interprete $i_{n}$ relation to the preoestrual $\mathrm{LH}$ release after progestagen treatment found by Cummrng et al. (I973).

In the three groups of animals treated with MAP beginning on days 4 , Io and $\mathrm{I}_{5}$, there was no uniform distribution of the various types of follicles at the end of the treatment. This may have consequences for the follicular phase following the end of 
MAP treatment and for the steroid synthesis in preovulatory follicles, especially those of type 4 and 5 .

As already mentioned, MAP treatment leads to prolongation of the second growth wave and allows a new follicular growth wave to start. A related question is whether MAP treatment influences steroid synthesis during treatment. According to ZrMBELMAN and SMiTh (I966) and CHOw et al. (I972), the oestrogen level during progestagen treatment is higher than during the normal luteal phase. In a pilot study, we compared the oestradiol-I $7 \beta$ concentration of large follicles on days $1_{5}, 16$ and 0 of the normal oestrous cycle with those on the same days during MAP treatment started on day Io. The results are given in table 3 and indicate that there is no clear difference between the groups. The oestrogen levels in treated animals seem to be only slightly lower. If we accept that MAP treatment does not prevent new follicular growth during treatment and inhibits only slightly steroid synthesis, we may wonder if the endometrial cycle will be disturbed by the treatment. On day IoT/7 (day o of the normal cycle), we found an endometrium with the oestrous phase in one of the 3 animals, and the pro-oestrous phase in the other two (KRUIP, unpublished). We did another study of the influence of MAP treatment on the endometrium (KRUIP, I973), and also found a pro-oestrous phase on day $4^{\prime} \mathrm{T}_{1} 3$, a phase very similar to the luteal phase of days 7 to Io of the normal cycle on day Io' 13 , and a phase similar to the luteal phase of days 8 to Io of the normal cycle on day I5Tr3. These different endometrial phases at the end of the treatment have to be changed into the oestrous phase within $27 \mathrm{I} / 2$ hours, $26 \mathrm{I} / 2$ hours and $34 \mathrm{I} / 2$ hours, respectively. In none of the groups was the condition of the endometrium during induced oestrus identical to the one seen during the normal non-synchronized oestrous.

TABLE 3

Concentration of oestradiol-17 ${ }^{\left({ }^{1}\right)}$ in the liquor folliculi of follicles on D15 D16 and D17 of the normal oestrous cycle and during treatment with $M A P$, started on DI"

\begin{tabular}{|c|c|c|c|c|}
\hline \multirow{2}{*}{ Day of cycle } & \multicolumn{4}{|c|}{ Concentration of oestradiol-17 $\beta$ in follicular fluid } \\
\hline & $\begin{array}{c}\text { No of } \\
\text { animal }\end{array}$ & Normal animals & $\begin{array}{l}\text { No of } \\
\text { animal }\end{array}$ & $\begin{array}{l}\text { MAP-treated } \\
\text { animals }\end{array}$ \\
\hline$-\cdots$ & & & & 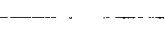 \\
\hline Day 15 & $\begin{array}{l}1 \\
2\end{array}$ & $127 \mathrm{ng} / \mathrm{ml}\left({ }^{2}\right)$ & $\begin{array}{l}7 \\
8\end{array}$ & $\begin{array}{r}\left.78 \mathrm{ng} / \mathrm{ml}^{(2}\right) \\
\left.106 \mathrm{ng} / \mathrm{ml}^{\mathbf{2}}\right)\end{array}$ \\
\hline Day-16 & $\begin{array}{l}3 \\
4\end{array}$ & $\begin{array}{r}485 \mathrm{ng} / \mathrm{ml}^{(2)} \\
45 \mathrm{ng} / \mathrm{ml}^{2}\left(^{4}\right)\end{array}$ & $\begin{array}{r}9 \\
10\end{array}$ & $\begin{array}{r}68 \mathrm{ng} / \mathrm{ml}\left(^{4}\right) \\
2.5 \mathrm{ng} / \mathrm{ml}\left(^{4}\right)\end{array}$ \\
\hline Day -17 & $\begin{array}{l}5 \\
6\end{array}$ & $\begin{array}{r}214 \mathrm{ng} / \mathrm{ml}\left({ }^{2}\right) \\
43 \mathrm{ng} / \mathrm{ml}\left({ }^{3}\right)\end{array}$ & $\begin{array}{l}11 \\
12\end{array}$ & $\begin{array}{l}318 \mathrm{ng} / \mathrm{ml}\left({ }^{3}\right) \\
125 \mathrm{ng} / \mathrm{ml}\left({ }^{2}\right)\end{array}$ \\
\hline
\end{tabular}

(1) Estimated by Dr. M A BLankenstein Fac. of Med. University of Rotterdam The Netherlands.

(2) Follicle type 1.

(3) Follicle type 2.

(4) Follicle type 3 . 
It is clear that the type of deviation in ovary and endometrium after oestrus synchronization with MAP is greatly determined by the day of the oestrous cycle on which the treatment is started. It might be possible that the statements of WIGGAN ( 1967 ) and WILLEMSE ( 1968 ), namely that subfertility in a herd is mainly caused by those animals which start the progestagen treatment on the second half of the cycle, have to be interpreted in this light. The disturbances in ovaries and endometria can be responsible for the occurrence of aging egg cells and prevention of fertilization by disturbance of sperm capacitation or sperm transport.

We offer the hypothesis that subfertility in the first oestrus after progestagen treatment may be the result of an insufficient suppression of follicular growth and steroid synthesis in the ovaries during treatment.

\section{Colloque : Control of sexual cycles in domestic animals} October 27-30, 1974, Nouzilly.

\section{RÉSUMÉ}

\section{CROISSANCE FOLLICULAIRE PENDANT LE CYCLE NORMAL ET APRÈS TRAITEMENT AVEC UN PROGESTAGÈNE CHEZ LA BREBIS}

L'activité ovarienne a été étudiée chez des Brebis de race Texel pendant un cycle œstrien, pendant et après un traitement de $I_{3}$ jours au MAP, aux niveaux micro-morphologique et cy tochimique. Parallèlement, on a recherché la concentration d'œestradiol- $77 \beta$ dans le liquide folliculaire pendant le cycle œstrien et pendant le traitement au MAP. Pendant le cycle cestrien, on discerne deux périodes de croissance des follicules. La première va du premier jour après l'ovulation jusqu'au dixième jour et la deuxième du sixième jour au dix-septième jour (jour du nouvel œstrus). Dans les follicules de la première période de croissance et dans les follicules de la deuxième période jusqu'au quatorzième jour inclus, on trouve peu d'œstradiol- 7 $\beta$ dans le liquide folliculaire. La concentration la plus élevée a été trouvée le seizième jour $(8,7 \mu \mathrm{g} / \mathrm{roo} \mathrm{g}$ de liquide folliculaire). Pendant l'œstrus on trouve seulement une concentration moyenne de $3,8 \mu \mathrm{g} / \mathrm{roo} \mathrm{g}$. On peut expliquer ces différences dans la synthèse d'œestrogène par la méthode cytochimique. Les follicules présentent du premier au seizième jour une activité aussi bien $3 \beta$ hydroxystéroïdéshydrogénase

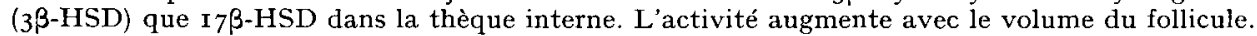
Elle est maximum le seizième jour. Pendant l'œestrus, il n'est pas possible de faire apparaître l'activité ${ }^{7}$ 3-HSD dans les follicules préovulatoires. Dans la granulosa, on ne trouve pas d'activité des stéroïdéshydrogénases. Le traitement au MAP maintient les follicules plus longtemps : l'activité $3 \beta$-HSD peut être constatée dans la granulosa des follicules qui persistent au moins six jours. De plus, le traitement au MAP ne prévient pas la croissance des nouveaux follicules et ne gêne pas la synthèse de stéroïde dans ces follicules. A l'arrêt du traitement, une croissance rapide de nouveaux follicules se produit. Certains follicules qui croissent rapidement présentent l'activité $3 \beta-H S D$ également dans la granulosa. Ces follicules existent chez les animaux en œestrus. En plus de l'activité $3 \beta$-HSD dans la granulosa, ces follicules présentent une activité $\mathbf{~} 7 \beta$-HSD dans la thèque interne. Ceci signifie qu'au cours du premier cestrus, après un traitement aux progestatifs, l'ovaire est capable de synthétiser des œstrogènes. Les follicules qui se maintiennent pendant le traitement peuvent persister un certain temps après l'arrêt du traitement, après quoi l'atrésie ou l'ovulation se produit. L'intervalle entre le début de l'œstrus et l'ovulation est normal. Les ovules qui pendant ou peu après l'œstrus peuvent être libérés proviennent de follicules normaux ou de follicules qui se développent rapidement ou de follicules maintenus. Les résultats sont mis en relation avec la fertilité qui est moindre au cours du premier œestrus après un traitement progestatif.

\section{REFERENCES}

AkVY L., 1960. Contribution à L'Histoenzymologie de l'ovaire. Z. Zellforsch., 51, 406-420.

BJERSING L., I967. On the morphology and endocrine function of granulosa cells in ovarian follicles and corpora lutea. Acta Endocrinol., 56, suppl. 125, I-23. 
Bjersixg L., Hay M. F., Kann G., Moor R. M., Naftolin F., Scaramuzzi R. J., Short R. P., Younglat E. Y., I972. Changes in gonadotrophins ovarian steroids and follicular morphology in sheep at oestrus. J. Endocr., 52, 465-479.

Brand A., De Jong W. H. R., r973. Qualitative and quantitative micromorphological investigations of the tertiary follicle population during the oestrous cycle in sheep. J. Reprod. Fert., 33, $43 \mathrm{I}-434$.

Brand A., VAN der Horst C. J. G., I972. Some endocrinological aspects of corpora lutea and of follicles during the oestrous cycle in sheep. Zuchthyg., 7 , 126-131.

Chow L. A., Thatcher W. W., Chenault J.C., Kalra P. S., Wilcox C. J., ig7z. Effects of MGA on bovine plasma ovarian steroids. J. Anim. Sci., 35, 239 (abst.).

Cox R. J., Mattner P. E., Thorburn G. D., I97I. Changes in ovarian secretion of oestradiol-I7 $\beta$ around oestrus in the sheep. J. Endocr., 49, 345-346.

Cumming I. A., Bcchmaster J. M., De B. Blockey M. A., Goding J. R., Winfield C. G., Baxter R. W., I973. Constancy of interval between luteinizing hormone release and ovulation in the ewe Biol. Reprod., 9, 24-29.

Deane H. W., 1952. Lipid droplets in granulosa cells as indication of atresia. Amer. J. Anat, 91, 363 .

Deane H. W., Hay M. F., Moor R. M., Rowson L. F. A., Short R. P., Ig66. The corpus luteum of the sheep : relationships between morphology and function during the oestrous cycle. Acta Endocrinol., 51, $245^{-263}$.

Dziuk P. J., Hinds F.C., Mansfield M. L., Baker R. D., rg64. Follicle growth and control of ovulation in the ewe following treatment with MAP. J. Anim. Sci., 23, 787-790.

Gomori $G_{\text {.., I }}$ I939. Microtechnical demonstration of phosphatase in tissue sections. Proc. Soc. Exp. Biol. . Y. Y ., 42, 23-26.

Guthrte H. D., Lamond D. R., Henricks D. M., Dickey J. F., I97o. Ovarian follicular changes in heifers treated with melengestrol acetate. J. Reprod. Fert., 22, 363-364.

Horst Vax der C. J. G., Brand A., ig7r. Preliminary investigation into the effect of administration of MAP on the formation of oestradiol-I $7 \beta$, hypotaurine and inositol in sheep. Tijdschr. Diergeneesk., 96, I $29 \mathrm{I}$.

Ḱellog D. A., Glenner G. G., I960. Histochemical localization of human term placental I7ß-oestradiol dehydrogenases : implications for the transhydrogenase reaction. Nature, 187, 763-765.

Krvip Th. A. M., I972. Steroid synthesis in the ovary of the Tewel ewe. A cytochemical analysis. Acta histochemica, Suppl. Bd. XII, 337.

Krvip Th. A. M., I973. Cytochemical investigations of ovary and endometrium of the Texel sheep during the oestrous cycle and after oestrous synchronization. Diss. Univ. Utrecht.

Lobel 13. L., LeYY E., r968. Enzymic correlates of development, secretory function and regression of follicles and corpora lutea in the bovine ovary. Acta Endocrinol., 59, Suppl. 132, I-63.

Moor R. M., HAY M. F., CALDwell B. V., I97r. The sheep follicle : relation between sites of steroiddehydrogenase activity, gonadotrophic stimulation and steroid production. J. Reprod. Fert., 27, 484485 .

Moore X. W., Barrett S., Brown J. B., Schindler J., Smith M. A., Smith B., I969. Oestrogen and progesterone content of ovarian vein blood of the ewe during the oestrous cycle. $J$. Endocr., 44, 55-62.

Moor R. MI., I 974. The ovarian follicle of the sheep : inhibition of oestrogen secretion by luteinizing hormone. J. Endocr., 61, 455-477.

PRAHBU V.K. K., WEIsz J., I970. liffect of blocking ovulation in the rat by pentobarbital on ovarian $3 \beta$-HSD. A histochemical study. Endocrinolog. 8\%, $48 \mathrm{I}-485$.

Robinson T. J., I968. The synchronization of the oestrous cycle and fertility. VI ${ }^{\mathrm{e}}$ Congr. Intern. Reprod. Anim. Insem. Artif., Paris, Vol. II, 1347-48.

Salisbury G. W., Hart, R. G., r97o. Gamete aging and its consequences. Biol. Reprod., Suppl.2, I-I3.

Scaramuzzi R. J., Caldwell B. V., Moor R. M., ig7o. Radioimmunoassay of LH and estrogen during the oestrous cycle of the ewe. Biol. Reprod., 3, I Io-IIg.

WIGGAN Ll. S., I967. Studies on fertility in sheep with special reference to artificial insemination and the control of ovarian cycles. Ph. D. thesis, University of London.

Willemse A. H., I968. Relation between the day of oestrous cycle at the time of the intra vaginal application of a MAP impregnated sponge and synchronization rate and conception rate in Texel sheep. $V^{\mathrm{e}}$ Congr. Intern. Reprod. Anim. Insem. Artif., Paris., Vol, II, I539-I 54I.

Zimbelmas R. G., Smith L. W., r966. Control of ovulation in cattle with melengestrol acetate. II. Effects on follicular size and activity. J. Reprod. Fert., 11, I93-20r. 
PLATE 
$a: 3 \beta-H S D$ activity in type 4 follicles. $\mathrm{V}=\mathrm{I} \times \mathrm{I} 6 \mathrm{0}$ $\mathrm{A}=$ granulosa $; \mathrm{B}=$ Theca interna.

$b$ : AP activity in type 4 follicles. $V=I \times I 60$

$\mathrm{A}=$ granulosa $; \mathrm{B}=$ Theca interna.

$c: 3 \beta-H S D$ activity in type 5 follicles. $\mathrm{V}=\mathrm{I} \times 25^{\circ}$

$\mathrm{A}=$ granulosa $; \mathrm{B}=$ Theca interna.

$d:$ I7 $\beta$-HSD act. in C.L. after MAP-treatment

$: A=$ granulosa luteal cells $; \mathrm{B}=$ Theca luteal cells 
Pl. I


Th. A.-M. KRUIP, A. BRAND 